\title{
Desafios, Planos e Ação
}

Os químicos brasileiros estão diante de um interessante cenário: foram recentemente feitas grandes descobertas de petróleo, ao mesmo tempo em que a produção de etanol da cana-de-açúcar aumenta rapidamente. Isso tem levado a indústria química a uma nova etapa de crescimento, baseada tanto no petróleo quanto nas matérias-primas de fonte renovável. Essa situação está criando muito entusiasmo, o que é facilmente compreensível. Entretanto, ela também requer muita análise, decisão e planejamento de muitas pessoas, inclusive dos pesquisadores.

De fato, também há notícias negativas. Dois anos depois do anúncio da sonhada auto-suficiência em petróleo, o déficit no seu comércio exterior já excede os cinco bilhões de dólares. Por outro lado, surgiram muitos problemas no uso de óleo de mamona na produção de biodiesel, que apenas confirmaram expectativas negativas criadas quando os planos governamentais foram anunciados. Os dois casos apenas ilustram uma idéia simples: não podemos confundir intenções e sonhos com realidades.

Há muitos desafios para a produção e utilização duráveis de matérias-primas da biomassa e vários problemas devem ser resolvidos, utilizando muito pensamento químico criativo.

Um primeiro desafio é a aguda dependência de importações no agronegócio brasileiro. Hoje, cerca de $50 \%$ dos compostos nitrogenados, $80 \%$ dos fosfatos e $90 \%$ do potássio usados em fertilizantes são importados. Essa situação deveria criar grande preocupação, mas ela pouco aparece nos documentos oficiais de C\&T. Os problemas de dependência de defensivos agrícolas não são menores, devido às fortes pressões de pragas sobre várias cultivos importantes. Juntos, fertilizantes e defensivos respondem por uma grande parte do déficit comercial químico brasileiro, pressionando o nosso ainda superavitário balanço comercial.

Essa situação é agravada pelo desperdício de uma parte significativa dos fertilizantes e defensivos usados no agronegócio: uma parte significativa jamais atinge os seus alvos em plantas ou pragas e termina por transformar-se em poluição, afetando negativamente o ambiente e as pessoas.

Soluções para esses problemas exigem ações interdisciplinares de curto e longo prazo que, por sua vez, criam tarefas e oportunidades para P\&D em Química. Há exemplos importantes que devemos lembrar: por exemplo, a vinhaça das usinas de álcool foi, até recentemente, um poluente muito agressivo, responsável por mortandades de peixes em vários rios. Hoje, a vinhaça é coletada, resfriada e usada nas plantações de cana. O repugnante cheiro da vinhaça apodrecida foi substituído pelo cheiro adocicado (alguns o consideram muito adocicado) do vinho de cana cozido. Isso exigiu um bocado de trabalho, inclusive o desenvolvimento de materiais adequados para coletar e transportar a vinhaça dos refervedores até os tanques de armazenagem.

Mesmo profissionais experientes reconhecem que há muitas lacunas no conhecimento químico e bioquímico sobre o destino dos fertilizantes e defensivos usados em plantas, animais e no solo. Criar esse conhecimento é essencial para a produção durável e em grande escala de alimentos, energia e matérias-primas da biomassa.

A Sociedade Brasileira de Química está trabalhando para atualizar mapas de oportunidades e desafios. O primeiro resultado visível deverá ser uma publicação na qual especialistas irão apresentar o estado da arte no uso de vários recursos naturais, com propostas para seu desenvolvimento em novos produtos. Com isso, poderemos atingir dois objetivos: compartilhar informações e estimular novas idéias, planos e, especialmente, ações conseqüentes.

Concluindo: temos perspectivas brilhantes, mas transformá-las em realidades requer muito trabalho, de muitas pessoas. Isso inclui uma grande quantidade de pesquisa química bem concebida e bem executada, no estado da arte. Essa é a contribuição que os pesquisadores e profissionais da Química podem fazer e farão.

Fernando Galembeck

$(I Q-U N I C A M P)$ 